\title{
Effect of various procedures on the viability of mouse embryos containing half the normal number of blastomeres
}

\author{
Y. Tsunoda* and Anne McLaren \\ M.R.C. Mammalian Development Unit, Wolfson House (University College London), \\ 4 Stephenson Way, London NWI $2 H E, U . K$.
}

\begin{abstract}
Summary. Half embryos produced from 8-cell or compacted stages were cultured in vitro for 1-2 days and transferred to oviducts or uteri of recipients at different stages of pseudopregnancy. The proportion of live fetuses was low $(8-12 \%)$, except for one group $(27 \%)$ in which half embryos were cultured in vitro for 1 day and transferred into oviducts on the 1 st day of pregnancy. Monozygotic twin production rate, however, was low (1 out of 10 ) even in this group. Fetal weight on the 18 th day of gestation was significantly lower after transfer of half embryos than after transfer of similarly treated but undivided embryos.

Half embryos produced from the 2-cell stage were inserted into empty zonae, embedded in agar, cultured in ligated mouse oviducts for 2-4 days and transferred to oviducts of recipient females on the 1 st day of pregnancy or pseudopregnancy. When twin embryos cultured for 2-3 days were transferred to pseudopregnant recipients together with control embryos, 4 sets of monozygotic twins and 5 singletons out of 10 sets of twin embryos were obtained on Days 18-19 of gestation, giving a survival rate of $65 \%$.
\end{abstract}

\section{Introduction}

Adult mice have been produced from embryos in which half the blastomeres were destroyed (Tarkowski, 1959a, b; Hoppe \& Whitten, 1972). Attempts have also been made to produce two young from a single mouse embryo (monozygotic twins); the success rate has generally been low (Mullen, Whitten \& Carter, 1970; Fiser \& Macpherson, 1976; Gärtner \& Baunack, 1981), with the exception of the experiment reported by Moustafa \& Hahn (1978). In sheep and cattle, a uniformly high success rate in the production of monozygotic twins has been reported (Willadsen, 1979, 1980; Willadsen, Lehn-Jensen, Fehilly \& Newcomb, 1981); the method involves the microsurgical separation of blastomeres, which are then transiently embedded in agar and cultured in vivo. In an attempt to devise a reliable method of producing monozygotic twins in the mouse, we have compared a number of different procedures.

\section{Materials and Methods}

Series 1. All mice belonged to the random bred MF1 strain (Olac). Embryos were collected in medium PB1 (Whittingham, 1971a), by flushing the oviducts and/or uteri, as early 8-cell stages in the morning or as compacted stages (8-16-cell) in the evening of Day 3 of pregnancy (day of vaginal

* Present address: National Institute of Animal Industry, Tsukuba Norindanchi PO Box 5, Ibaraki 305, Japan. 
plug = Day 1) from superovulated or naturally ovulated females. The zona pellucida was removed with $0.5 \%$ pronase (Bowman \& McLaren, 1970), and the embryos were washed three times with modified Krebs-Ringer bicarbonate (Whittingham, 1971b). Each zona-free embryo was mechanically divided into 2 equal groups of blastomeres with a fine-bore glass pipette under liquid paraffin, and both halves were cultured for 1 day $(18-27 \mathrm{~h})$ or 2 days $(40-50 \mathrm{~h})$ at $37^{\circ} \mathrm{C}$ in an atmosphere of $95 \%$ air, $5 \% \mathrm{CO}_{2}$.

In the first experiment (Table 1), 1-5 sets of twin embryos that had developed to the stage of late morula (after 1 day of culture) or blastocyst (after 2 days of culture) were transferred to one uterine horn or oviduct of pseudopregnant females on Days 1, 2, 3 or 4. In all instances, 1-10 undivided morulae or blastocysts, cultured in vitro from zona-free 8-cell or compacted embryos, were transferred to the contralateral side of the reproductive tract. All mice were killed on Day 17-20 of gestation, and the numbers of implantations, resorptions and live fetuses, and weights of the fetuses were recorded.

In a further experiment (Table 3), the two halves (twin embryos) that had developed to the morula stage from compacted half embryos during culture for 1 day, together with 4 similarly cultured zona-free undivided 8-cell to morula embryos obtained from non-albino $Q$ strain females mated with non-albino $(+/+)$ males, were transferred to the oviducts of Day-l pseudopregnant MF1 females. The recipients were allowed to go to term.

Series 2. Embryos at the 2-cell stage were obtained on Day 2 of pregnancy from superovulated or naturally ovulated F1 (CBA $\times$ C57BL/6), non-albino $Q$ or C57BL/6 strain females mated with nonalbino Q strain males.

Monozygotic pairs of agar-coated single blastomeres were produced according to the procedures of Willadsen (1979), modified as described below. The zona pellucida was removed mechanically using a Leitz micromanipulator (Group I in Tables 5 and 6) or by treatment with pronase (Table 4 and Group II in Tables 5 and 6). Both single blastomeres were inserted into evacuated mouse blastocyst zonae. Each monozygotic pair of embryos was embedded in a small cylinder of $1 \%$ agar in phosphate-buffered saline (PBS) (Table 4 and Group II in Tables 5 and 6) and sometimes re-embedded in a slightly larger cylinder of $1.25 \%$ agar in PBS (Group I in Tables 5 and 6). The agar chip with a single set of twin embryos was transferred to one ligated oviduct, ovarian bursa or uterine horn of a Day-1 or Day-3 pseudopregnant or pregnant MF1 female. After an interval of 4 days (for Day 1 recipients) or 2 days (for Day 3 recipients), the agar chips were recovered and the half embryos were examined. After release from the agar, both half embryos, now at the morula or blastocyst stage, were transferred to the oviduct of a Day-1 pseudopregnant MF1 female, on their own (Group a in Table 6) or with 2 MF1 morulae (Group c) or to the oviduct of a Day-1 pregnant MF1 female (Group b). All mice were killed on Day 18 or 19 of gestation, and the number of implantations and live fetuses was recorded.

The statistical significance of the results was determined by $t$ test (Table 2) and $\chi^{2}$ analysis.

\section{Results}

\section{Series 1}

Of the 775 sets of twin embryos cultured in vitro, 603 sets $(78 \%)$ developed to the morula or blastocyst stage. Of the 313 and 550 control undivided zona-free embryos at the 8-cell or compacted stage, $294(94 \%)$ and $529(96 \%)$ respectively developed to morulae or blastocysts after culture in vitro.

Table 1 summarizes the development of control and half embryos cultured in vitro for different periods before transfer to oviducts or uteri of recipients at different pseudopregnant stages.

Viability of control embryos. After transfer to the uterus of recipients on Day 3 of pseudopregnancy, the proportion of live fetuses was higher for compacted embryos cultured in vitro 


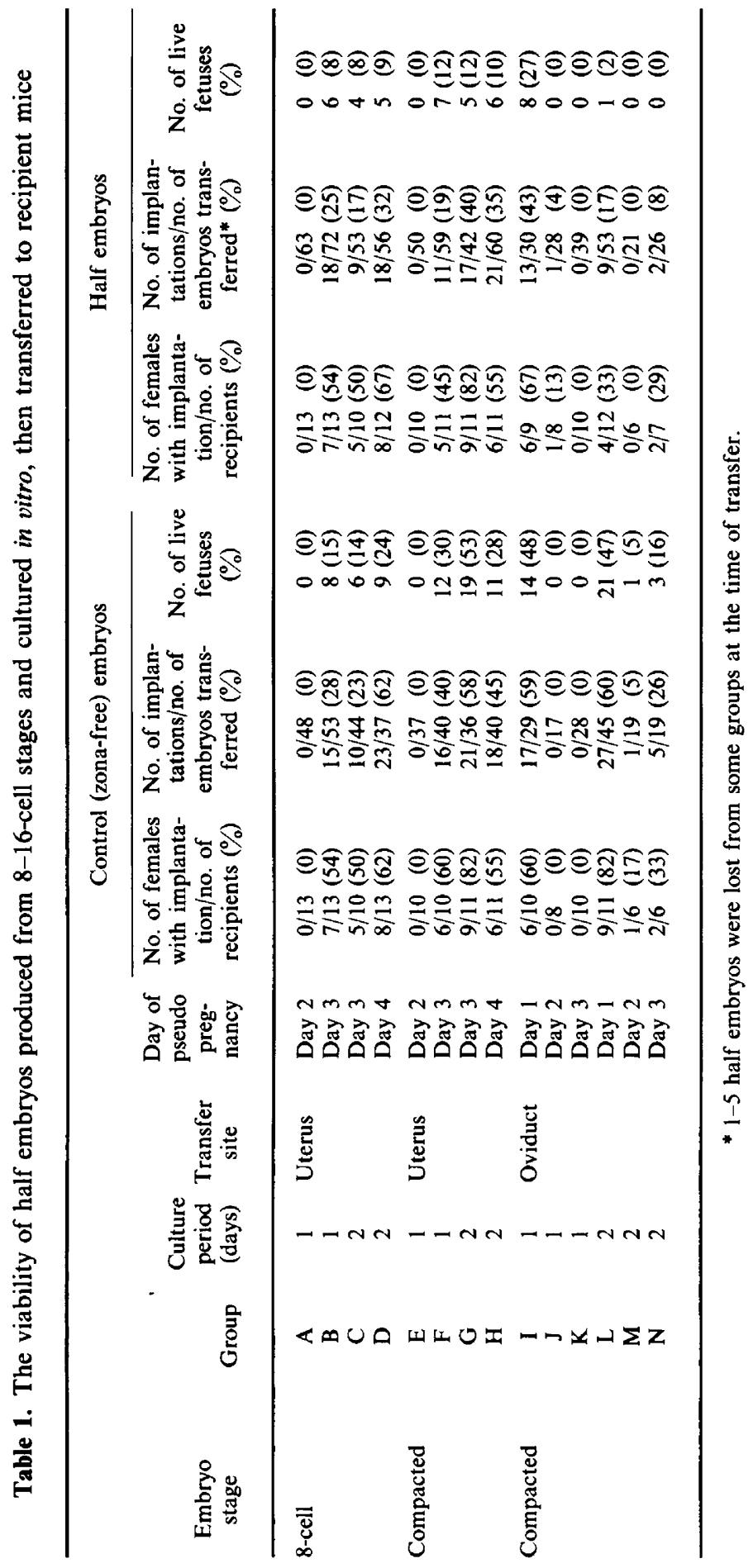


for 2 days ( $53 \%$ in Group G) than for the most successful cultured pre-compacted 8-cell embryos $(24 \%$, in Group D), although pregnancy and implantation rates did not differ. When control embryos cultured for 1 or 2 days were transferred to oviducts on Day 1 of pseudopregnancy, high pregnancy $(60 \%, 82 \%)$ and implantation $(59 \%, 60 \%)$ rates, and high proportions of live fetuses $(48 \%, 47 \%)$ were obtained.

Viability of half embryos. As shown in Table 1, the proportions of live fetuses after transfer of half embryos were consistently low compared with the control groups. The highest proportion of live fetuses, $27 \%$, was obtained when half embryos were cultured for 1 day and transferred to the oviducts on the 1st day of pseudopregnancy (Group I).

Table 2 shows fetal weight on Day 18 of gestation after transfer of control and half embryos. The combined comparison of all groups showed that there was a significant $(P<0.001)$ difference between half embryos and control embryos ( $1.04 \pm 0.23$ compared with $1.17 \pm 0.20 \mathrm{~g})$.

Table 2. Body weight on Day 18 of pregnancy of live mouse fetuses obtained after transfer of undivided (control) and half embryos

\begin{tabular}{|c|c|c|c|c|c|c|}
\hline \multirow{2}{*}{$\begin{array}{l}\text { Group } \\
\text { (as in } \\
\text { Table 1) }\end{array}$} & \multicolumn{3}{|c|}{ Control embryos } & \multicolumn{3}{|c|}{ Half embryos } \\
\hline & $\begin{array}{l}\text { No. of } \\
\text { recipients }\end{array}$ & $\begin{array}{l}\text { No. of } \\
\text { fetuses }\end{array}$ & $\begin{array}{l}\text { Mean } \pm \text { s.d. } \\
\text { body wt }(\mathrm{g})\end{array}$ & $\begin{array}{l}\text { No. of } \\
\text { recipients }\end{array}$ & $\begin{array}{l}\text { No. of } \\
\text { fetuses }\end{array}$ & $\begin{array}{l}\text { Mean } \pm \text { s.d. } \\
\text { body wt }(\mathrm{g})\end{array}$ \\
\hline \multicolumn{7}{|l|}{$\mathrm{B}, \mathrm{C}, \mathrm{D}, \mathrm{F}$, } \\
\hline $\begin{array}{l}\text { G,H,I,L } \\
\text { D }\end{array}$ & $\begin{array}{r}27 \\
3\end{array}$ & $\begin{array}{r}60 \\
4\end{array}$ & $\begin{array}{l}1.17 \pm 0.20 \\
0.96 \pm 0.12\end{array}$ & $\begin{array}{r}20 \\
4\end{array}$ & $\begin{array}{r}31 \\
5\end{array}$ & $\begin{array}{l}1.04 \pm 0.23^{* * *} \\
0.98 \pm 0.15\end{array}$ \\
\hline $\mathrm{F}$ & 2 & 4 & $1.20 \pm 0.07$ & 3 & 5 & $0.98 \pm 0.19^{* *}$ \\
\hline $\mathrm{H}$ & 3 & 8 & $1.07 \pm 0.08$ & 2 & 6 & $0.83 \pm 0.15^{* *}$ \\
\hline I & 4 & 12 & $1.14 \pm 0.14$ & 4 & 7 & $1.07 \pm 0.22^{*}$ \\
\hline
\end{tabular}

${ }^{*} P<0.05,{ }^{* *} P<0.01,{ }^{* * *} P<0.001$ compared with control embryo values.

Table 3. The viability of mouse twin embryos produced from compacted embryos and cultured in vitro for 21 to $24 \mathrm{~h}$, after transfer to the oviduct of a recipient on Day 1 of pseudopregnancy

\begin{tabular}{cccccc}
\hline & \multicolumn{2}{c}{ Control embryos } & & \multicolumn{2}{c}{ Twin embryos } \\
\cline { 2 - 3 } \cline { 5 - 6 } $\begin{array}{c}\text { Recipient } \\
\text { no. }\end{array}$ & $\begin{array}{c}\text { No. of embryos } \\
\text { transferred }\end{array}$ & $\begin{array}{c}\text { No. of live } \\
\text { young }\end{array}$ & & $\begin{array}{c}\text { No. of embryos } \\
\text { transferred }\end{array}$ & $\begin{array}{c}\text { No. of live } \\
\text { young }\end{array}$ \\
\hline 1 & 4 & 2 & & 0 & \\
2 & 4 & 3 & 2 & 0 \\
3 & 4 & 0 & 2 & 0 \\
4 & 4 & 3 & 2 & 0 \\
5 & 4 & 2 & & 2 & 0 \\
6 & 4 & 4 & & 2 & 0 \\
7 & 4 & 2 & & 2 & 0 \\
8 & 4 & 0 & & 2 & 0 \\
9 & 4 & 0 & & 2 & 0 \\
10 & 4 & 2 & & 2 & 0 \\
Total & 40 & $18(45 \%)$ & & 20 & 0 \\
\hline
\end{tabular}


Table 3 shows the results of a further experiment, using the conditions previously found optimal (i.e. as in Group I, Table 1). One set of monozygotic twins and 1 young were obtained from half embryos. Overall survival rate was significantly $(P<0.05)$ lower for half embryos $(15 \%)$ than for controls $(45 \%)$.

\section{Series 2}

As shown in Table 4, only in ligated oviducts did a high proportion of half embryos develop to morula or blastocyst stage.

Table 4. Effect of transfer site on the recovery rate and the development of half embryos produced from 2-cell stages in the mouse

\begin{tabular}{|c|c|c|c|c|}
\hline \multirow[b]{2}{*}{ Transfer site } & \multirow[b]{2}{*}{$\begin{array}{l}\text { Day of pseudo- } \\
\text { pregnancy }\end{array}$} & \multicolumn{3}{|c|}{ No. of embryos } \\
\hline & & Transferred & $\begin{array}{c}\text { Recovered } \\
(\%)\end{array}$ & $\begin{array}{c}\text { Developed into } \\
\text { morula or } \\
\text { blastocyst }(\%)\end{array}$ \\
\hline Oviduct & Day 1 & 97 & $39(40)$ & $25(64)$ \\
\hline Ovarian bursa & Day 1 & 37 & $19(51)$ & $3(16)$ \\
\hline Uterus & Day 1 & 10 & 0 & - \\
\hline Uterus & Day 3 & 22 & $11(50)$ & 0 \\
\hline
\end{tabular}

Table 5. The development of pairs of half embryos, produced from 2-cell stages, during culture in ligated mouse oviducts

\begin{tabular}{|c|c|c|c|c|}
\hline & \multicolumn{4}{|c|}{ Culture period } \\
\hline & \multicolumn{3}{|c|}{ Group I* } & \multirow{2}{*}{$\frac{\text { Group II } \dagger}{3 \text { days }}$} \\
\hline & 2 days & 3 days & 4 days & \\
\hline No. of twin pairs transferred & 19 & 67 & 12 & 63 \\
\hline No. of embryos recovered $(\%)$ & $27(71)$ & $90(67)$ & $9(38)$ & $47(37)$ \\
\hline No. of twin pairs & 11 & 43 & 4 & 20 \\
\hline No. of morulae and blastocysts $(\%)$ & $19(70)$ & $82(91)$ & $4(44)$ & $34(72)$ \\
\hline No. of twin pairs & 7 & 37 & 2 & 13 \\
\hline
\end{tabular}

* Mechanical removal of zona.

$\dagger$ Pronase removal of zona.

Table 5 shows the in-vivo development of half embryos during culture in ligated oviducts. In Group I, in which zonae pellucidae were mechanically removed, the recovery rate of embryos was significantly $(P<0.01)$ higher after 2 and 3 days than after 4 days. The proportion of embryos at the morula or blastocyst stage was significantly $(P<0.001)$ higher when embryos were recovered 3 days after transfer than after 2 or 4 days. After 2 days, most of the remaining embryos were at the 416-cell stage, but after 4 days most had degenerated. The proportion of morulae and blastocysts was significantly $(P<0.001)$ lower in Group II (pronase-treated) than in Group I.

Table 6 shows in-vivo development of twin embryos that were recovered from ligated oviducts at the morula to blastocyst stage. Some of the groups contain only very small numbers of embryos. Of the half embryos exposed to pronase (Group II), or cultured for 4 days, none implanted. Group I 
embryos cultured for 2 or 3 days fared better: when only those females are considered that became pregnant, either by natural mating (Group b) or by control embryo transfer (Group c), more than half the embryos developed into live fetuses (19 out of 36). Twin embryos gave results not significantly different from control embryos. The proportion of live fetuses developing from twin embryos transferred, together with control embryos, to pseudopregnant recipients (Group c, 13 out of 20 embryos) was higher than but not significantly different from that obtained by transfer to pregnant females (Group b, 6 out of 16 embryos), for 2 and 3 days' incubation combined. The proportion of monozygotic twins was also higher in Group c (4 out of a possible 10 sets of twin embryos) than in Group b (1 out of 8).

Table 6. The viability of twin embryos, produced from 2-cell stages, cultured for 2-4 days in ligated oviducts, after transfer to recipient mice

\begin{tabular}{|c|c|c|c|c|c|c|c|}
\hline & \multicolumn{7}{|c|}{ Culture period } \\
\hline & \multicolumn{6}{|c|}{ Group I } & \multirow{3}{*}{$\begin{array}{c}\text { Group II } \\
3 \text { days } \\
a\end{array}$} \\
\hline & \multicolumn{2}{|c|}{2 days } & \multicolumn{3}{|c|}{3 days } & \multirow{2}{*}{$\begin{array}{l}4 \text { days } \\
b+c\end{array}$} & \\
\hline & $\mathrm{b}$ & c & a & $\mathrm{b}$ & $\mathrm{c}$ & & \\
\hline No. of recipients & 2 & 3 & 5 & 10 & 13 & 2 & 5 \\
\hline No. of recipients pregnant & 2 & 2 & 3 & 6 & 8 & 1 & 0 \\
\hline \multicolumn{8}{|l|}{ No. of embryos transferred } \\
\hline Half embryos & 4 & 6 & 18 & 20 & 32 & 4 & 25 \\
\hline Control embryos & 0 & 6 & 0 & 0 & 29 & 2 & 0 \\
\hline \multicolumn{8}{|l|}{$\begin{array}{l}\text { No. of embryos transferred } \\
\text { in pregnant recipients }\end{array}$} \\
\hline Half embryos & 4 & 4 & 10 & 12 & 16 & 0 & 0 \\
\hline Control embryos & 0 & 4 & 0 & 0 & 18 & 2 & 0 \\
\hline \multicolumn{8}{|l|}{ No. of implantations } \\
\hline Half embryos (no. of twin pairs) & $2(0)$ & $4(2)$ & $6(2)$ & - & $13(6)$ & 0 & 0 \\
\hline Control embryos & - & 2 & - & - & 16 & 2 & - \\
\hline \multicolumn{8}{|l|}{ No. of live fetuses $(\%)$} \\
\hline Half embryos (no. of twin pairs) & $2(0)$ & $3(1)$ & $4(1)$ & $4(1)$ & $10(3)$ & 0 & 0 \\
\hline Control embryos & - & 2 & - & - & 14 & 2 & - \\
\hline
\end{tabular}
a Twin pairs transferred on their own to oviduct of Day-1 pseudopregnant recipient.
b Twin pairs transferred on their own to oviduct of Day-1 pregnant recipient.
c Twin pairs transferred with 2 control morulae to oviduct of Day-1 pseudopregnant recipient.

\section{Discussion}

Only Moustafa \& Hahn (1978) have reported a high success rate for producing monozygotic twin mice (8 sets of live young out of 20 sets of transferred twin embryos). They bisected 8-16-cell embryos with or without zonae by micromanipulation, cultured them for 24 to $30 \mathrm{~h}$ and then transferred them to recipient uteri. Our results (Series 1 , Tables $1 \& 3$ ), using a similar but not identical technique, were not as good. The viability of half embryos produced from 8-16-cell compacted embryos after transfer to recipient uteri was only $10-12 \%$, much lower than that of zonafree control embryos (Groups $\mathrm{F}-\mathrm{H}$ in Table 1). A relatively high proportion of live fetuses on Days 17-20 of pregnancy $(27 \%$ ) was obtained in one group (Group I in Table 1), in which compacted embryos were divided into two halves, cultured in vitro for 1 day and transferred to oviducts on the 1st day of pseudopregnancy. It seems that mouse half embryos develop better when transferred to oviducts than to uteri, perhaps because the transferred embryos have an extra few days to increase their cell number before implantation. Even so, only one set of live twins was obtained out of 10 sets 
transferred. The low viability of mouse half embryos and the low incidence of twins in Series 1 of the present study are in agreement with the results of Fiser \& Macpherson (1976), Mullen et al. (1970) and Gärtner \& Baunack (1981).

Because of our disappointing initial results, we carried out a further series of experiments, using a procedure similar to that devised by Willadsen (1979). Series 2 , which gave markedly higher survival rates for half embryos, differed from Series 1 in the following respects.

(1) Stage of embryos: 8-16-cell stages were used in Series 1, but 2-cell stages in Series 2. Willadsen (1980) reported that there was no apparent difference in the ability of 2-, 4- or 8-cell embryos to yield live monozygotic twins in sheep. In the mouse, no comparative assessment has yet been made of the ability of halved 2-, 4- or 8-cell embryos to give rise to live young. Single blastomeres gave rise to viable fetuses when isolated at the 2-cell stage (Tarkowski, 1959a, b) but not at the 4-8-cell stage (Rossant, 1976).

(2) Difference in donor strain. Embryos were collected from random-bred MF1 females mated with MF1 males in Series 1, but from $F_{1}$, $Q$ or C57BL/6 females mated with $Q$ strain males in Series 2. Since the 3 different strains in Series 2 gave similar results, and since previous attempts to make monozygotic twins from Q-strain embryos using essentially the methods of Series 1 have met with little success (A. McLaren \& M. H. L. Snow, unpublished results), strain differences were probably not a major factor in the higher survival rate of half embryos in the second series.

(3) Removal of zonae. Zonae pellucidae were removed by pronase treatment (Bowman \& McLaren, 1970) in Series 1 and Group II in Series 2, but mechanically in Group I of Series 2. Treatment with pronase appeared to have little or no adverse effect on the development of 8-cell embryos to blastocysts in vitro, but had a significant adverse effect on their ability to develop as live fetuses after transfer. Similarly with 2-cell embryos in Series 2, most of those treated with pronase developed to morulae or blastocysts during culture in ligated oviducts, but none developed into live fetuses after transfer.

(4) Method of culture. Half embryos were cultured in vitro in Series 1, but were transferred to ligated mouse oviducts in Series 2 . In the latter series, embryos were also inserted into empty zonae and embedded in agar. The disappointing results following transfer of in-vitro cultured half embryos indicate that ligated oviducts provide a better environment for the further development of half embryos than does in-vitro culture, even in the mouse in which methods for in-vitro culture of early cleavage stages are well established (Brinster, 1969). When the embryos were recovered from the ligated oviducts and removed from agar, most were still in the zona pellucida. This may not be essential for further development, because when half embryos produced from compacted embryos and cultured in vitro for 1 day were inserted into empty zonae before transfer to oviducts, the proportion of live fetuses did not increase compared with that obtained after transfer without zonae. The half embryos produced from 2-cell stages cannot be directly transferred into oviducts of Day-1 pseudopregnant recipients without agar, because most of the transferred embryos would escape from the zona during and/or after transfer, and could then adhere to the oviduct and fail to develop (Bronson \& McLaren, 1970; Modlinski, 1970). It seems to be important for half embryos to be given an opportunity to increase their cell number before implantation, since the proportion of live fetuses in Group I of Table $1(8 / 30,27 \%)$, in which half embryos cultured in vitro were transferred into oviducts of Day-1 pseudopregnant recipients, was significantly $(P<0.05)$ higher than when they were transferred to uteri $(18 / 161,11 \%$, for Groups $F+G+\mathbf{H}$ in Table 1$)$.

Tarkowski (1959a, b) reported that mouse half embryos surviving to the 12 th day of gestation were already at the same stage of development and the same size as control embryos, and the birth weight of live young from half embryos was also not different from that of newborn control mice. In contrast, the present study showed that the body weight of Day-18 fetuses developing from half embryos was significantly lower than that of control fetuses. We observed no abnormalities in the live fetuses from half embryos. Although Tarkowski $(1959 \mathrm{a}, \mathrm{b})$ reported that 6 mice obtained from half embryos were fertile, the developmental and reproductive ability of mice from half embryos needs to be examined further. 
We thank Dr S. Willadsen, A.R.C. Institute of Animal Physiology, Cambridge, U.K., for instruction on the technique of micromanipulation of embryos, and Dr T. Sugie, National Institute of Animal Industry, Tsukuba, Japan, and Dr D. G. Whittingham, M.R.C. Experimental Embryology and Teratology Unit, Carshalton, U.K., for their critical advice. Y.T. was supported by the Ministry of Science and Technology of Japan.

\section{References}

Bowman, P. \& McLaren, A. (1970) Viability and growth of mouse embryos after in-vitro culture and fusion. $J$. Embryol. exp. Morph. 23, 693-704.

Brinster, R.L. (1969) Mammalian embryo culture. In The Mammalian Oviduct, pp. 419-444. Eds E. S. E. Hafez \& R. J. Blandau. University Chicago Press.

Bronson, R. \& McLaren, A. (1970) Transfer to the mouse oviduct of eggs with and without the zona pellucida. J. Reprod. Fert. 22, 129-137.

Fiser, P.S. \& Macpherson, J.W. (1976) Development of embryonic structures from isolated mouse blastomeres. Can. J. Anim. Sci. 56, 33-36.

Gärtner, K. \& Baunack, E. (1981) Is the similarity of monozygotic twins due to genetic factors alone? Nature, Lond. 292, 646-647.

Hoppe, P.C. \& Whitten, W.K. (1972) Does X chromosome inactivation occur during mitosis of first cleavage? Nature, Lond. 239, 520-521.

Modlinski, J.A. (1970) The role of the zona pellucida in the development of mouse eggs in vivo. J. Embryol. exp. Morph. 23, 539-547.

Moustafa, L.A. \& Hahn, J. (1978) Experimentelle erzeugung von identischen mäusezwillingen. Dtsch. Tieraerztl. Wochenschr. 85, 242-244.

Mullen, R.J., Whitten, W.K. \& Carter, S.C. (1970) Studies on chimeric mice and half-embryos. In
Annual Report of the Jackson Laboratory, pp. 67-68. Bar Harbor, Maine.

Rossant, J. (1976) Postimplantation development of blastomeres isolated from 4- and 8-cell mouse eggs. $J$. Embryol. exp. Morph. 36, 283-290.

Tarkowski, A.K. (1959a) Experiments on the development of isolated blastomeres of mouse eggs. Nature, Lond. 184, 1286-1287.

Tarkowski, A.K. (1959b) Experimental studies on regulation in the development of isolated blastomeres of mouse eggs. Acta theriol. 3, 191-267.

Whittingham, D.G. (1971a) Survival of mouse embryos after freezing and thawing. Nature, Lond. 233, 125126.

Whittingham, D.G. (1971b) Culture of mouse ova. $J$. Reprod. Fert., Suppl. 14, 7-21.

Willadsen, S.M. (1979) A method for culture of micromanipulated sheep embryos and its use to produce monozygotic twins. Nature, Lond. 277, 298-300.

Willadsen, S.M. (1980) The viability of early cleavage stages containing half the normal number of blastomeres in the sheep. J. Reprod. Fert. 59, 357-362.

Willadsen, S.M., Lehn-Jensen, H., Fehilly, C.B. \& Newcomb, R. (1981) The production of monozygotic twins of preselected parentage by micromanipulation of non-surgically collected cow embryos. Theriogeno$\operatorname{logy} 15,23-29$. 